Syntax Literate : Jurnal Ilmiah Indonesia p-ISSN: 2541-0849

e-ISSN : 2548-1398

Vol. 5, No. 6, Juni 2020

\title{
PENGARUH MEDIA ANIMASI TERHADAP KETERAMPILAN MENULIS CERITA MURID KELAS V SD SE-KOTA MAKASSAR
}

\section{Syahruni Hambali, Erwin Akib dan Sitti Aida Azis}

Universitas Muhammadiyah Makassar

Email: syahruni789@gmail.com,Erwin@unismuh@ac.id dan bunda.ipass@gmail.com

\section{Abstract}

The main problem in this study is how is effect using animation media on story writing skill of fifth grade students of elementary school in Makassar City. This study aims to know how is effect using animation media on story writing skill of fifth grade students of elementary school in Makassar City. The kind of this study is a quasi-experimental study that aims to determine the effect of the use of animation media on story writing skills of fifth grade students of elementary school in Makassar City as many as 112 students, grouped into two groups, namely the fifth grade students of Pongtiku Elementary School and the fifth grade of Kaccia Elementary School as many as 56 people as an experimental group/class, and fifth grade students in Sangir elementary school and fifth grade in Labuang Baji elementary school as a control group/class. The study was conducted during 10 meetings, which is divided into 5 meetings in the experimental class and 5 meetings in the control class. Data is collected by using a test of Indonesian learning outcomes in the form of pre-test and post-test, The results of descriptive analysis was obtained as follows, shows that students' ability to write stories is higher, where the scores of experimental class students are higher than those of the control class. Meanwhile, the results of the t-test showed that the significant difference in the t-table value with the t-test value was proven by the t-test. Based on the results of the study, it can be concluded that the animation media influences to story writing skills in fifth grade students of elementary school in Makassar City.

Keywords: Animation media skill, Animation media and the result of study

\section{Abstrak}

Masalah utama dalam penelitian ini adalah bagaimana pengaruh penggunaan media animasi terhadap keterampilan menulis cerita murid kelas V SDN se-Kota Makassar. Penelitian ini bertujuan untuk mengetahui bagaimana pengaruh penggunaan media animasi terhadap keterampilan menulis cerita murid kelas $\mathrm{V}$ SDN se-Kota Makassar. Jenis penelitian ini adalah penelitian quasi eksperimen yang bertujuan untuk mengetahui pengaruh penggunaan media animasi terhadap keterampilan menulis cerita murid kelas V SD Negeri se-Kota Makassar sebanyak 112 murid, dikelompokkan atas dua kelompok, yaitu siswa kelas V SD Pongtiku dan kelas V SD Kaccia sebanyak 56 orang sebagai kelompok/ kelas eksperimen dan siswa kelas V SD Sangir dan kelas V SD Labuang Baji sebanyak 56 orang sebagai kelompok/ kelas kontrol. Penelitian dilaksanakan selama 10 kali pertemuan yang terbagi 5 kali pertemuan pada kelas eksperimen dan 5 kali pertemuan pada kelas 
kontrol. Pengambilan data dilakukan dengan menggunakan tes hasil belajar bahasa Indonesia berupa pre-test dan post-test. Adapun hasil analisis deskriptif yang diperoleh sebagai berikut, menunjukkan bahwa siswa kemampuan dalam menulis cerita lebih tinggi, dimana skor murid kelas eksperimen lebih tinggi daripada kelas kontrol. Sementara itu, dari hasil uji-t menunjukkan bahwa perbedaan signifikan nilai t-tabel dengan nilai t-test terbukti dengan t-test. Berdasarkan hasil penelitian maka dapat disimpulkan bahwa media animasi berpengaruh terhadap keterampilan menulis cerita pada murid kelas V SD Negeri se-Kota Makassar.

Kata kunci: Keterampilan media animasi, media animasi dan hasil belajar

\section{Pendahuluan}

Pendidikan merupakan harapan dan cita-cita luhur bagi para pemimpin bangsa ini khususnya untuk orang tua. Selain itu Pendidikan merupakan hal yang penting dalam kehidupan seseorang terlebih untuk menghadapi persaingan dan kompetisi global yang semakin tinggi memaksa setiap individu untuk lebih cerdas dalam menyikapi hal tersebut guna memenuhi kebutuhan hidupnya. Atas dasar itulah, maka seseorang dituntut untuk meningkatkan kualitas hidupnya melalui pendidikan agar dapat bersaing dan berkompetensi secara global (Mukson, 2017).

Pembelajaran bahasa Indonesia di sekolah dasar (SD) merupakan bagian penting dalam kerangka pengembangan pendidikan maksimal yang bertujuan untuk menciptakan sumber daya manusia yang memiliki kemampuan berbahasa yang optimal. Salah satu kompetensi menulis yang diharapkan dikuasai oleh murid, yaitu menulis karangan.Karangan merupakan satuan bahasa terlengkap, dalam hierarkan merupakan suatu gramatikal tertinggi atau terbesar, karangan ini direalisasikan dalam bentuk karangan yang utuh (buku, serf ansiklopedia, dan sebagainya), paragraf.Kalimat atau kata yang membawa amanat yang lengkap (Kridalaksana, 2001).

Adapun ayat yang berkaitan dengan tulisan antara lain terdapat dalam surah $\mathrm{Al}$ Qalam:68:1

Artinya: Nun, demi pena dan apa yang mereka tulis/catat.

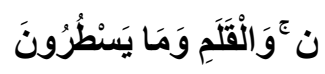

Banyak hadist diriwayatkan bahwa Rasulullah saw bersabda: sesungguhnya yang pertama kali Allah ciptakan adalah al Qalam atau pena. Allah berfirman kepada qalam "Tulislah!. Al Qalam bertanya apa yang akan aku tulis.

Menulis merupakan suatu proses yang menggunakan lambang-lambang atau sejumlah huruf untuk menyusun, mencatat, dan mengomunikasikan, serta dapat menampung aspirasi atau makna yang ingin disalurkan kepada orang lain (Darmadi, 2016).

Pencapaian peranan dan urgensi menulis sebagaimana yang terurai tentu sulit diperoleh. Hal ini disebabkan oleh minat murid pada kegiatan menulisyang masih kurang. Salah satu jenis karangan yang dinilai menjadi momok dan menakutkan bagi murid SD se-Kota Makassar adalah tulisan narasi karena ada beberapa aspek yang perlu 
diperhatikan.Selain penggunaan kalimat efektif, ejaan dan tanda baca, penyusunan sebuah tulisan dalam bentuk cerita juga memerlukan teknik tersendiri sehingga tulisan yang dibuat merupakan hasil buah pikiran seseorang yang bagus untuk dibaca.Salah satu teknik yang perlu diperhatikan adalah penyajian bahan-bahan dalam tulisan sebagai hasil pengidraan penulis yang dapat dijadikan sebagai gambaran memperkuat tulisan narasi.

Berdasarkan hasil observasi sebelum penelitian di beberapa sekolah dasar di Makassar diantaranya SD Negeri Pongtiku Makassar, SD Negeri Kaccia Makassar, SD Negeri Labuang Baji Makassar, dan SD Negeri Makassar, proses pembelajaran tidak berjalan dengan baik ketika penyajian materi keterampilan menulis narasi. Hasil keterampilan menunjukkan hanya sekitar $60 \%$ murid yang sudah memiliki keterampilan menulis cerita.Hasil ini jauh dari standar ketuntasan belajar minimal (SKBM) nasional, yaitu 75\%. Selain itu, masalah yang tampak adalah (1) keterampilan murid dalam menulis masih rendah; (2) murid kurang memiliki keaktifan dan kreativitas dalam belajar; (3) murid sulit berinspirasi dan sulit menciptakan ide/gagasan; (4) sulit menulis cerita secara kronologis.

Kondisi tersebut berdampak pada hasil belajar menulis cerita di sekolah SD Negeri Labuang Baji Makassar dan SD Negeri Kaccia Makassar. Berdasarkan hasil pengamatan penulis bahwa hasil pembelajaran menulis tahun 2017, nilai murid hanya mencapai rata-rata 60. Demikian halnya dengan nilai ketuntasan yang tidak mencapai KKM, yakni $75 \%$ murid yang mendapat nilai 65 ke atas.

Berdasarkan hal ini semestinya guru mampu menggunakan bahkan membuat media pembelajaran untuk membantu murid dalam proses belajar mengajar di kelas. (Sagala, 2011) mengatakan bahwa dengan mengenal media pengajaran dan memahami cara-cara penggunaannya akan sangat membantu tugas para guru dalam meningkatkan efektivitas proses pembelajaran. Pemanfaatan media animasi yang merupakan bagian dari multimedia diharapkan dapat membantu proses pembelajaransehingga peserta didik dapat beraktivitas mengoptimalkan kongnitifnya.

Adapun media animasi berorientasi pendidikan karakter dibuat dengan menggunakan program perangkat lunak adobe flash (video animasi), meski demikian penggunaan media dalam pembelajaran hendaknya dapat mengasah kecerdasan dan kompetensi murid.

Berdasarkan pemaparan tersebut, maka ditetapkan judul dalam penelitian ini yaitu "Pengaruh Media Animasi terhadap Keterampilan Menulis Cerita Murid Kelas V SD se-Kota Makassar".

Adapun rumusan masalah pada penelitian ini adalah (1) Apakah terdapat pengaruh penggunaan media animasi terhadap keterampilan menulis cerita murid kelas V SD se-Kota Makassar?(2) Bagaimanakah gambaran penggunaan media animasi terhadap keterampilan menulis cerita murid kelas V SD se-Kota Makassar?

Adapun tujuan penelitiannya adalah (1) Mengetahui apakah ada pengaruh penggunaan media animasi terhadap menulis cerita murid kelas V se-Kota Makassar. 
(2) Mengetahui bagaimana gambaran media animasiterhadap kemampuan menulis cerita murid kelas V SD se-Kota Makassar.

Media dalam kehidupan bermasyarakat terdapat ciri utama yakni adanya hubungan di antara anggotanya. Hubungan itu berlangsung sedemikian rupa, sehingga terjadi proses saling mempengaruhi. Peningkatan efisiensi dan efektivitas tersebut sebagian bergantung kepada faktor penunjang, yakni sarana dan prasarana. Media berasal dari bahasa Latin dan merupakan bentuk jamak dari kata medium yang secara harfiah berarti perantara atau pengantar.Jadi dapat dipahami bahwa media adalah perantara atau pengantar dari pengirim ke penerima pesan. (Widya, 2008), mengemukakan bahwa media adalah semua bentuk perantara yang dipakai orang menyebar ide, sehingga ide atau gagasan itu sampai kepada penerima. Adapun beberapa jenis media pengajaran yang dapat digunakan dalam proses pengajaran yaitu: Pertama, media grafis seperti gambar, foto, grafik, bagan atau diagram, poster, kartun, komik, dan lain-lain. Media grafis sering juga disebut media dua dimensi,yakni mempunyai ukuran panjang dan lebar. (Hamalik, 2005) memberi batasan bahwa media pendidikan adalah alat, metode dan teknik digunakan dalam rangka mengaktifkan komunikasi dan interaksi antar guru dan murid dalam prose pendidikan dan pengajaran disekolah. Dari pengertian serta batasan-batasan yang dikemukakan oleh para ahli di atas, terdapat beberapa persamaan di antaranya, bahwa media adalah segala sesuatu yang dapat digunakan untuk menyalurkan pesan dari indera penglihatan ke otak sehingga dapat merangsang pikiran, perasaan, perhatian dan minat perhatian murid sedemikian rupa sehingga proses belajar terjadi. Dari beberapa pendapat tentang media pengajaran dapat disimpulkan bahwa proses dan hasil belajar para murid menunjukkan perbedaan yang berarti antara pengajaran tanpa media dengan media pengajaran yang menggunakan media.

Media Animasi Menurut (Salim \& Gould, 2003) animasi adalah proses penciptaan efek gerak atau efek perubahan bentuk yang terjadi selama beberapa waktu (morphing). (Suheri, 2006) mengatakan bahwa animasi merupakan kumpulan gambar yang diolah sedemikian rupa sehingga menghasilkan gerakan. Salah satu keunggulan animasi adalah kemampuannya untuk menjelaskan suatu kejadian secara sistematis dalam tiap waktu perubahan. media animasi pembelajaran adalah media audio visual yang merupakan kumpulan gambar bergerak dan suara berisikan materi pembelajaran yang ditampilkan melalui media elektronik projektor sebagai usaha untuk menciptakan pembelajaran yang aktif dan menyenangkan.

Kelebihan media animasi adalah penggabungan unsur media lain seperti audio, teks, video, image, grafik, dan sound menjadi satu kesatuan penyajian, sehingga mengakomodasi sesuai dengan modalitas belajar murid. Selain itu, dapat mengakomodasi murid yang memiliki tipe visual, auditif, maupun kinestetik (Sudrajat, 2010).

Keterampilan Menulis Menulis merupakan suatu proses yang terdiri dari kegiatan (1) pramenulis (pengalaman pramenulis meliputi menggali ide, mengingat dan memunculkan ide, menghubungkan-hubungkan ide sehingga dimunculkan topik yang 
menarik untuk ditulis) kemudian diikuti oleh penyusunan kerangka karangan, (2) penyusunan dan buram (usaha untuk menyusun teks dengan menuangkan semua ide tentang topik yang telah dibatasi, (3) penyuntingan (pemberian kesemutan untuk berpikir kembali, melihat kembali, dan menyusun kembali teks yang telah disusun), (4) pembahasandan pengkreasian (mencari masukan untuk memperbaiki tulisan serta mengkreasikan ide dalam bentuk yang berbeda). Keempat proses membawa implikasi pada penilaian keterampilan menulis. Dengan kata lain penilaian menulis tidak sematamata bertumpu pada hasil tetapi juga mempertimbangkan proses penulisan. Menulis adalah segenap rangkaian kegiatan seseorang dalam rangka mengungkapkan gagasan dan menyampaikannya melalui bahasa tulis kepada orang lain agar mudah dipahami (Nurudin et al., 2010).

Adapun ciri-ciri tulisan yang baik menurut Mc.Mahan \& Day dalam Tarigan (2008: 7) adalah (a) Jujur: jangan coba memalsukan gagasan/ide (b) Jelas jangan membingungkan para pembaca (c) Singkat: jangan memboroskan waktu para pembaca. (d) Usahakan keanekaragaman: panjang kalimat yang beraneka ragam; berkaryadengan penuh kegembiraan. Menurut D'Angelo (dalam Tarigan 2008), tujuan menulis adalah memproyeksikan sesuatu mengenai diri seseorang. Tulisan mengandung nada yang serasi dengan maksud dan tujuannya. Dapat dijelaskan bahwa menulis tidak hanya mengharuskan memilih suatu pokok pembicaraan yang cocok dan sesuai, tetapi juga harus menentukan siapa yang akan membaca tulisan tersebut, serta apa maksud dan tujuan ia menulis.

Menurut (Jauhari, 2013) manfaat menulis yaitu (1) Peningkatan kecerdasan, (2) Pengembangan daya inisiatif dan kreativitas, (3) Penumbuhan keberanian, (4) Pendorong kemauan dan kemampuan mengumpulkan informasi.

Keterampilan menulis merupakan keterampilan yang sangat kompleks dibanding dengan keterampilan lainnya. Karena didalam keterampilan menulis diperlukan pemahaman tentang konsep yang akan dibahas, pemahaman mengenai apa yang dibahas, penyusun kalimat yang jelas serta penggunaan tanda baca yang benar. Selain itu harus ada perbedaan yang mendasar antara bahasa tulis dan bahasa lisan. Menulis biasanya menuliskan sesuatu yang sudah ada, kemudian orang melakukan pengembangan/ mengembangkannya, karenanya dibutuhkan banyak referensi dan biasanya proses kreatif ini bersifat ilmiah. Sedangkan mengarang adalah menuangkan sesuatu berupa ide atau gagasan yang ada di pikiran kita dalam bentuk tulisan, biasanya proses kreatifnya bersifat nonilmia.

\section{Metode Penelitian}

Penelitian ini merupakan penelitian Quasi eksperimen. Tindakan yang dilakukan untuk melihat adakah pengaruh yang signifikan penggunaan media animasi dalam model pembelajaran langsung terhadap hasil belajar Bahasa Indonesia murid kelas V SD Negeri se-Kota Makassar. Penelitian ini dilaksanakan dengan metode Quasieksperimen.Kelompok pertama kelas eksperimen melakukan pembelajaran dengan media animasi yang mengintegrasikan nilai. Kelompok kedua adalah kelompok kelas 
kontrol atau kelompok pembanding melakukan pembelajaran secara normal. Dalam penelitian ini, tidak dilakukan randomisasi untuk memasukan subjek ke dalam kelompok eksperimen dan kelompok kontrol, dengan menggunakan control group design. Adapun subjek penelitian ini adalah di SDN Kaccia, SDI Pingtiku I, SDN Bertingkat Labuang Baji, dan SDN Sangir Kota Makassar dengan jumlah seluruh siswa adalah 112 murid. Teknik pengambilan sampel yang di-gunakan adalah Cluster Random Sampling. Adapun sampel yang digunakan adalah siswa kelas V SDN Kaccia 28 murid, SDI Pingtiku I 28 murid, SDN Bertingkat Labuang Baji 28 murid, dan SDN Sangir 28 murid

Teknik pengumpulan data serta instrument yang digunakan adalah teknik tes. Dimana Teknik pengumpulan data yang digunakan dalam penelitian ini adalah tes awal dan tes akhir. Akan tetapi sebelum instrumen tes diujikan, perlu diadakan uji validitas. Validitas digunakan untuk me-ngetahui ketetapan alat penilaian terhadap konsep yang dinilai sehingga betul-betul menilai apa yang seharusnya dinilai.

Teknik analisis data yang digunakan dalam penelitian ini terbagi atas dua yaitu analisis statistik deskriptif dan analisis statistik inferensial. teknik analisis data, digunakan tiga macam uji yang terdiri dari uji normalitas, uji homogenitas, dan uji hipotesis.

\section{Hasil dan Pembahasan}

\section{A. Hasil Penelitian}

Data penelitian ini tentang keterampilan menulis cerita murid Sekolah Dasar Kelas V se-Kota Makassar. Penelitian ini bertujuan untuk mengetahui penggunaan media animasi terhadap keterampilan menulis cerita murid sekolah dasar kelas $\mathrm{V}$ seKota Makassar. Penelitian ini menggunakan metode eksperiment, yakni menempatkan subjek penelitian kedalam 4 sekolah yang dibedakan menjadi kategori kelas kontrol (SD Sangir dan SD Pongtiku Kota Makassar) dan kelas eksperiment (SD Labuang Baji dan SD Kaccia Kota Makassar. Sebelum pembelajaran dalam kelas dilaksanakan baik kelompok kelas kontrol maupun kelompok kelas eksperiment dilakukan pre test. Hal ini bertujuan untuk mengetahui penguasaan kemampuan menulis cerita murid yang akan diajarkan dan sebagai data awal untuk mengetahui kondisi awal sampel. Namun demikian, sebelum analisis data dengan uji perbedaan tersebut atau uji $\mathrm{t}$, perlu dilakukan uji analisis yang meliputi uji normalitas dan uji homogenitas. Proses analisis data penelitian diuraikan sebagai berikut. 
Tabel 1 Hasil Uji Normalitas Postes Kelas Kontrol dan Eksperiment

\begin{tabular}{|c|c|c|c|c|c|c|c|}
\hline \multicolumn{8}{|c|}{ Tests of Normality } \\
\hline & \multirow[b]{2}{*}{ Kelompok } & \multicolumn{3}{|c|}{ Kolmogorov-Smirnov $^{\mathrm{a}}$} & \multicolumn{2}{|c|}{ Shapiro-Wilk } & \multirow[b]{2}{*}{ Sig. } \\
\hline & & Statistic & Df & Sig. & Statistic & df & \\
\hline \multirow[t]{2}{*}{ Pretest } & $\begin{array}{l}\text { Kelas } \\
\text { Kontrol }\end{array}$ & ,095 & 56 &, $200^{*}$ & ,969 & 56 &, 157 \\
\hline & $\begin{array}{l}\text { Kelas } \\
\text { Eksperimen }\end{array}$ &, 105 & 56 &, 188 & ,965 & 56 & , 104 \\
\hline \multirow[t]{2}{*}{ Postest } & $\begin{array}{l}\text { Kelas } \\
\text { Kontrol }\end{array}$ & 109 & 56 & ,095 & ,977 & 56 & ,347 \\
\hline & $\begin{array}{l}\text { Kelas } \\
\text { Eksperimen }\end{array}$ &, 144 & 56 & ,006 & ,963 & 56 &, 085 \\
\hline
\end{tabular}

Dari tabel Uji normalitas Pretest dan Posttest terdapat signifikan berdistriusi normal sehingga terdapat peningkatan dari sebelum mendapatkan perlakuan yang diterapkan pada kelas kontrol dan eksperimen. Tabel Uji normalitas Xhitung $<$ Xtabel sehingga dapat disimpulkan bahwa hasil dari uji yang lakukan berdistribusi normal.

\section{Tabel 2 Hasil Uji Homogenitas Pretest dan Posttest Kelas Kontrol dan Kelas} Eksperimen Kota Makassar

Test of Homogeneity of Variances

Postest

\begin{tabular}{rccc}
\hline Levene Statistic & df1 & df2 & Sig. \\
\hline, 190 & 1 & 110 &, 663 \\
\hline
\end{tabular}

Berdasarkan table output "Test of Homogenety of Variance" di ketahui nilai signifikan. Variabel hasil belajar pada murid kelas control dan kelas eksperiment adalah 0,663. Karena nilai Sig. 0,663>0,05 maka sebagaimana dasar pengambilan keputusan dalam uji homogenitas di atas dapat disimpulkan bahwa data hasil belajar murid kelas control dan kelas eksperiment adalah sama dan homogeny.

\section{Tabel 3 Hasil Analisis Anova Postest Kelompok Kelas Kontrol dan Kelas \\ Eksperiment \\ ANOVA

\begin{tabular}{lrlccc}
\hline & & & & & \\
\hline & um of Squares & Df & Mean & & \\
\hline Between & 2914,650 & 1 & 2914,650 & 88,405 &, 000 \\
Groups & & & & & \\
Within & 3626,635 & 110 & 32,969 & & \\
Groups & & & & & \\
Total & 6541,285 & 111 & & & \\
\hline
\end{tabular}


Berdasarkan hasil table output SPSS diatas, diketahui nilai sig. adalah sebsar 0.000. Karena nilai sig. $0,000<0,05$, maka sesuai dengan dasar pengambilan keputusan dalam uji $\mathrm{F}$ dapat disimnpulkan bahwa hipotesis diterima. Hal tersebut sejalan dengan nilai $F_{\text {hitung }}$ adalah 88,405 . Karena nilai $F_{\text {hitung }} 88,405>F_{\text {tabel }} 6,90$, maka sebagaimana dasar pengambilan keputusan dalam uji $\mathrm{F}$ dapat disimpulkan bahwa hipotesis diterima.

Hasil uji-t setelah diberi perlakuan (post-test) adalah $\mathrm{f}_{\text {hitung }}>\mathrm{f}_{t}(88,405>6,90)$ berarti antara kelas eksperimen dengan kelas kontrol perbedaannya signifikan. Ratarata nilai postest kelas eksperimen adalah 86,56 dan rata-rata nilai postes kelas kontrol adalah 76,36. Hasil ini menunjukkan kemampuan murid setelah diberi perlakuan berbeda, yakni kelas eksperimen menggunakan media animasi dan kelas kontrol tanpa media animasi dalam pembelajaran. Terlihat kemampuan murid kelas eksperimen lebih tinggi daripada kelas kontrol ditunjukkan dengan adanya perbedaan nilai rata-rata murid. Berdasarkan perhitungan $\mathrm{F}$ dapat disimpulkan bahwa pembelajaran menggunakan media animasi dapat meningkatkan hasil belajar murid. Dengan demikian hipotesis yang menyatakan "pembelajaran dengan memanfaatkan media animasi lebih efektif dibandingkan dengan pembelajaran tanpa media animasi pada murid kelas V SD se-Kota Makassar", diterima.

\section{B. Pembahasan}

Data yang telah dianalisis menunjukkan bahwa tidak ada signifikan perbedaan pre-test antara kelas eksperimen dan kelas kontrol. Hal ini dapat dilihat sebelum perlakuan bahwa skor rata-rata kelas eksperimen adalah 73,95 sedangkan kelas kontrol adalah 75,99. Setelah melakukan perlakuan, nilai rata-rata kelas eksperimen adalah sebesar 86,56, sedangkan kelas kontrol nilai rata-ratanya sebesar 76,36. Ini berarti bahwa kemampuan menulis cerita murid dari kedua kelas secara signifikan perbedaan. Kelas eksperimen lebih tinggi dari kelas kontrol. Temuan ini menunjukkan bahwa dengan menggunakan media animasi adalah salah satu media pembelajaran terbaik dalam mengajar menulis cerita. Media animasi adalah media yang menarik untuk dipertontonkan pada murid, karena dengan cerita yang ada dalam film animasi tersebut mampu mengajak murid untuk berimajinasi dan meluangkan cerita yang ia dengar dengan menulis. Hal ini dapat membuat murid termotivasi dalam belajar Berdasarkan hasil t-test, penulis menemukan bahwa ada perbedaan yang signifikan antara pre-test kelas eksperimen dan kelas kontrol. Satu hal yang berbeda dari kelas eksperimen untuk mengontrol kelas, itu teknik pengajaran yang digunakan selama perlakuan. Kelas eksperimen diajar dengan menggunakan media animasi berupa film kartun. Itu berbeda dengan kelas kontrol yang diajar dengan menggunakan teknik tradisional. Selanjutnya berdasarkan log belajar murid, penulis mengamati bahwa murid di kelas eksperimen biasanya menikmati belajar menulis cerita dengan menggunakan media animasi. Para murid menyatakan bahwa menulis cerita dengan melihat film itu lebih menarik. 


\section{Kesimpulan}

Berdasarkan hasil analisis data dan pembahasan hasil pada bab sebelumnya, penulis menyimpulkan bahwa peningkatan keterampilan menulis SD Negeri Kelas V se-Kota Makassar dalam menulis cerita melalui penggunaan media animasi itu sangat baik. Adapun hasil analisis deskriptif yang diperoleh sebagai berikut, menunjukkan bahwa kemampuan murid dalam menulis cerita lebih tinggi, karena skor murid kelas eksperimen lebih tinggi dari kelas kontrol. Dilihat, dari hasil uji-t menunjukkan bahwa perbedaan signifikan nilai t-tabel dengan nilai t-test terbukti dengan t-test. Jadi hasil dari uji-t berarti Fhitung $>F \operatorname{tabel}(88,405>6,90)$ berarti $H_{0}$ ditolak dan $H_{1}$ diterima.

Sedangkan respon murid terhadap media animasi berada pada kategori tinggi dengan persentase $80 \%$, artinya murid memberikan respon positif terhadap penggunaan media animasi selama pembelajaran.Penulis juga menyimpulkan bahwa ada perbedaan yang signifikan antara post-test kelas eksperimen dan kelas kontrol. Dengan kata lain, penggunaan media animasi dapat meningkatkan kemampuan menulis cerita murid di kelas eksperimen dibandingkan kelas kontrol dan murid sangat menikmati belajar menulis cerita dengan menggunakan media animasi yang diterapkan. 


\section{BIBLIOGRAFI}

Darmadi, S. (2016). Ownership concentration, family control, and auditor choice. Asian Review of Accounting.

Hamalik, O. (2005). Pengembangan sumber daya manusia manajemen pelatihan ketenagakerjaan pendekatan terpadu. Jakarta: Bumi Aksara.

Jauhari, M. N. R. (2013). Pengembangan Modul Fisika Berbasis Problem Based Learning Pada Materi Fluida Untuk Siswa Cerdas Istimewa-berbakat Istimewa. Inkuiri, 2(03).

Kridalaksana, H. (2001). Kamus Linguistik edisi ketiga. Jakarta: PT Gramedia Pustaka Utama.

Mukson, M. (2017). Pengaruh Status Sosial Ekonomi Terhadap Motivasi Belajar Mahasiswa Pendidikan Guru Sekolah Dasar Universitas Muhadi Stiabudi Brebes Tahun 2017. Syntax Literate; Jurnal Ilmiah Indonesia, 2(7), 116-129.

Nurudin, M., Watanabe, M., Ohta, S., Hardiyanto, E. B., Mendham, D., Inoue, Y., ... Heriyanto, J. (2010). Application of Soil Color to Access productivity of Acacia mangium Plantation in Indonesia. The Japanese Forest Society Congress The Japanese Forest Society Congress 121, 444. THE JAPANESE FORESTRY SOCIETY.

Sagala, S. (2011). The concept and meaning of learning. Bandung: Alfabeta.

Salim, S., \& Gould, A. (2003). Improved astrometry and photometry for the Luyten catalog. II. Faint stars and the revised catalog. The Astrophysical Journal, 582(2), 1011.

Sudrajat, A. (2010). Standar Pelaksanaan Proses Pembelajaran.

Suheri, A. (2006). Animasi Multimedia Pembelajaran. Jurnal Media Teknologi, 2(1), 27-33.

Widya, Y. (2008). Pedoman Perawatan Kesehatan Anak. Bandung: Penerbit Yrama Widya. 